\begin{tabular}{c} 
Volume and Issues Obtainable at Center for Sustainability Research and Consultancy \\
Responsible Education, Learning and Teaching in Emerging Economies \\
ISSN: 2708-4310 \& (E): 2708-4183 \\
Volume 2: No.2, December 2020 \\
CSRᄃ \\
Journal homepage: www.publishing.globalcsrc.org/relate \\
\hline
\end{tabular}

\title{
Learning of Islamic Law in Contemporary Universities: Case Study of Faculty of Sharī'ah \& Law of International Islamic University Islamabad and Islamic Legal Studies Program of Harvard Law School
}

Naureen Akhtar, University Gillani Law College, Bahauddin Zakariya University, Multan, Pakistan Pakistan

Atia Madni, Faculty of Shariah \& Law, International Islamic University Islamabad, Pakistan Rais Nouman Ahmed, University Gillani Law College, Bahauddin Zakariya University, Multan, Pakistan

Corresponding author's email address: naureen.akhtar@bzu.edu.pk

ARTICLE DETAILS

History

Revised format: Nov 2020

Available Online: Dec 2020

\section{Keywords}

Islamic Law, Islamic Legal Studies Program, Harvard law School, Faculty of Shari'ah \& Law, International Islamic University Islamabad.

JEL Classification I20, A22

\section{ABSTRACT}

Purpose: This research paper aims to study the standing of learning of Islamic Law in contemporary universities. The present study highlights the significance of Islamic Law learning to the legal practitioners (Bar) and legal academicians in general and to the judges (Bench) in particular. This paper endeavors to conduct a case study of learning of Islamic law in contemporary universities in Muslim and Non-Muslim jurisdictions.

Methodology: For the purpose of this research paper, two universities have been selected where departments of Islamic law learning are established, i.e., Faculty of Sharī'ah \& Law of International Islamic University, Islamabad and Harvard Islamic Legal Studies Program of Harvard law School. This study explores that how far the above-mentioned institutions in various jurisdictions have been successful in imparting Islamic Law education among their law students. It follows discussion on the relevancy of Islamic law learning and its understanding in the solution of contemporary issues of the modern world.

Findings: This paper finds that Islamic law, being based on divine guidance, is the complete code of conduct and therefore, provides guidelines to discover and find out the solutions of all issues of modern world to Bar, academicians and Bench.

(C) 2020 The authors, under a Creative Commons AttributionNonCommercial 4.0

Recommended citation: Akhtar, N., Madni, A. and Ahmed, R. N. (2020). Learning of Islamic Law in Contemporary Universities: Case Study of Faculty of Sharī'ah \& Law of International Islamic University Islamabad and Islamic Legal Studies Program of Harvard Law School. Responsible Education, Learning and Teaching in Emerging Economies, 2 (2), 85-89. 


\section{Introduction}

'Islam' has been declared by Allah Almighty Himself, the last divine guidance that is revealed on the Last Prophet Muhammad as per ruling in the verse 5:3 of the Holy Quran (Sūrah Al-Mā'ida: 3; Ibn Rajab Bin Al-Hassan, 2001). Islam is not only a religion but a deen which implies a complete code of conduct (Khan, n.d). It is universal and timeless. Therefore, it exhibits the capability to meet the needs of people of all times and places. It deals not only with the matters of beliefs but also provides rulings for the matters pertaining to the conduct. Moreover, it provides guidelines for social, political, economic and legal systems. Islam is the only religion that has successfully made reconciliation between worldly affairs and spirituality (Leghaei, 2019).

Rene David and John E. C. Brierley (1978) in his book titled, Major Legal Systems in the World Today: An Introduction to the Comparative Study of Law, has classified the laws into families like Romano-Germanic family, Common Law family and Socialist Law family. Moreover, the author placed the law of India, Muslim law, Laws of the Far East, Africa and Malagasy in a single group and argued that all of them are inspired from the conceptions of law and social order which were altogether different from the legal systems prevailing in the West (Minattur, 1979).

Various legal systems are prevailing in the world today, like common legal system, civil legal system, pluralistic legal system etc. Besides these legal systems, Islamic legal system also exists in the world for 1400 years ago. Islamic legal system has the peculiar characteristic of being divine guided apart from other legal system which are totally man made (https://guides.law.sc.edu/c.php?g=315476\&p=2108388). In religious systems, the only legal system that exists today is the 'Islamic Legal System'. The Jewish, Christian and Buddhist systems never appear as legal systems in the history and nor do they exist today. It is only the Islamic Legal system that based on religion that has survived till present (Nyazee, 2016). The ability of the Islamic legal system to meet political, administrative and social needs of the people have been proven beyond doubt (Hassan, 2010). Imran Ahsan Khan Nyazee in his book Outlines of Islamic Jurisprudence laid a stress on this viewpoint and said,

"Islamic law has no parallel in history. It has, indeed, been the world's most successful legal system, a system that has been practiced for more than fourteen hundred years by many peoples and nations with widely differing cultures and local conditions. If the current population projections are to be believed, Islamic law will, within another hundred years, to be practiced by more than half the population of the world" (Nyazee, 2012).

The question arises that, is there any significance of Islamic law or Shari' $a h$ in present world today? It appears, with the passage of the time, that the study or learning of Islamic law or Shari' 'ah becomes more and more important for legal academicians, legal practitioners and judges. Its significance is unequivocal. Islamic law held a unique position in the structure of the legal system of Muslim States especially (Anderson, 1960).

There is an escalating tradition that Islamic law has become a subject of strategic significance not only in Muslim majority jurisdictions but also in Muslim minority jurisdictions. The abovementioned statement is substantiated with the establishment and existence of Faculty of Sharī'ah \& Law (FSL) of International Islamic University Islamabad (IIUI) in a Muslim Majority jurisdiction and Islamic Legal Studies Program (ILSP) of Harvard Law School (HLS) in a Muslim minority jurisdiction. For the purpose of this research work, the above mentioned two institutions have been selected to conduct a case study to evaluate the learning and relevancy of Islamic law in the world today. 


\section{Learning of Islamic Law in Contemporary Universities}

Learning Shari' 'ah as law was marginalized in the universities during the colonial era. Some of the Western scholars of Islamic law even gave statement about the disappearance of the subject of Islamic law from the curriculum. The factual reality is reverse from what was predicted. The faculties, colleges and institutions that teach Islamic law not only increased in Muslim majority jurisdictions but also in Muslim minority jurisdictions and even in states which declare and propound to be secular. Teaching and learning of Islamic law gained momentum in the last century (Masud, 2005).

Position of Islamic law in the state legal system, particularly in late $19^{\text {th }}$ century, is transformed from the jurist's law to the statutory law. Furthermore, the role of 'Ulamā' or Muslim Jurists as interpreter of the transmitted text (Nass) of the Holy Quran and Sunnah has been undermined. Moreover, the Islamic law is applicable through judicial courts in family matters only, thereby, an effort to restrict the Sharī' $a h$ to the implementation of Islamic Personal law (Layish, 2014).

In this part of the present article, standing of learning of Islamic Law in contemporary universities of the world today is analyzed. It would be difficult if this research paper tried to cover all the universities of the world to overview the learning of Islamic Law. For the sake of convenience, for the purpose of this study, Pakistan from the Majority Muslim jurisdictions and United States of America from Muslim minority jurisdictions have been selected. Two universities, International Islamic University Islamabad (IIUI) and Harvard University (HU), have been selected among contemporary universities. Furthermore, for the sake of convenience, as a case study two institutions, ILSP of HU and FSL of IIUI, have been selected where Islamic law is taught as an independent subject.

In Pakistan, many universities impart legal education where statutory law is taught. Many statutes of Pakistan are those made by the Britishers and Pakistan being the colony of Britishers adopted those laws which are based on Common legal system. Islamic law is also taught to the law students both at bachelor (LLB) and master (LLM) levels in the form of subjects like, Islamic jurisprudence, Muslim Personal Law etc. The reason of teaching both laws, statutory law and Islamic law, is required because Pakistan is declared as an Islamic Republic as per Article 2 of the Constitution of Pakistan, 1973 and no law can be promulgated against the injunctions of the Holy Quran and Sunnah as per ruling in Article 227 of the Constitution of Pakistan, 1973.

There is only one university in all over the state of Pakistan where both statutory and Islamic law is taught in details and that is IIUI. FSL of IIUI undertakes to impart the knowledge of Shari 'ah as well as law to its students in its true letter and spirit. FSL of IIUI provides legal education with emphasis on Islamic law and to develop greater interaction and understanding between Shari 'ah and contemporary laws. FSL aims to produce highly qualified law graduates who are well versed in both Shari 'ah and law. The faculty is a pioneer institution which is trying to bridge the gap between the Islamic law and contemporary laws. The faculty is not only trying to trace the harmonization between Shari' 'ah and law but also trying to contribute in the development of Islamic law in accordance with the needs of the time (https://www.iiu.edu.pk/?page id=6881). The delivery of subject matter with best and appropriate methodology is required to impart the knowledge of both, Shari 'ah and law, to the students (Kayode \& Hashim, 2014).

This article argues that law graduates, who have been taught Shari' $a$ h and law both in their education, are far better than those law graduates who take few courses in the name of Islamic law like, Islamic Jurisprudence and Muslim Personal law. Moreover, this article argues that law graduates of such institution, like FSL of IIUI, are capable of better understanding of Islamic law on a point under discussion in the court of law being legal practitioners. Likewise, they are capable of implementing Islamic law in true letter and spirit being judges because of their better 
insight and understanding of Sharī'ah rulings on various issues. Similarly in academics, such law graduates teach both Sharì' $a h$ and state law on a legal point.

Harvard University is the oldest institution imparting higher education in United States of America. It was established in 1636. Currently, this university is headed by Lawrence S. Bacow who is 29th President of the HU (https://www.harvard.edu/about-harvard/harvard-glance ). HU comprises of 11 academic units and one of these units is HLS. Since 1950, HLS offers a course on Islamic law from time to time. Later in 1991, ILSP of HLS was established formally which was a manifestation of HLS students' growing interest in the study of Islamic Law. ILSP of HLS aims to foster excellence in the study of Islamic Law in an atmosphere of open inquiry. ILSP of HLS provides two facilities. One of these two is, The Fellowship Program, which offers fellowship of 09 months which may extendable for 03 months more, to the scholars across the globe so that they may get benefits from Library's rich source material on Islamic Law. On the other hand, ILSP of HLS also offers, The Student Support Program, where scholarships and research grants are provided to the students of HLS each year (https://ilsp.law.harvard.edu/whowe-are / ).

\section{Relevancy of Learning Islamic Law along with the Statutory law to Legal Academicians, Bar and Bench}

This part of the article addresses the key question of this writing that, does learning Islamic law or Sharī'ah as a law is significant today for not only Legal academicians but also for legal practitioners and judges? This research article argues that academicians related to law field study are in need to seek proficiency both in statutory law as well as in Islamic law in Pakistan. This is because Pakistan has mixed legal system, containing elements of both, Common legal tradition and Islamic legal tradition. The legal system of Pakistan is characterized by pluralism (Jamali, 2015). Otherwise, academicians could not bring out the desired results of bringing all the laws of Pakistan within the realm of Sharī'ah. Pakistan is facing challenges, since its inception in 1947, to make its laws all-together Sharī'ah based and Sharī'ah compliant. The process of Islamization of laws, in Pakistan, started in 80's when General Zia-ul-Haq took the charge of the state as a Martial law administrator. Legal academicians can participate actively in the process of Islamization of laws in Pakistan if they have a training of understanding of Sharī 'ah as a law and also have skillful knowledge about the statutory laws.

Furthermore, this paper argues that legal academicians need to seek expertise in utilization of various sources of law, schools of thought, methodologies applied by various jurists while giving legal rules and rules of interpretation to explore the real intention of the law-maker behind the legislation. Legal academicians are entrusted with a responsibility to reproduce the original text of law, which is in Arabic and English languages respectively, in native languages so that people at large may understand the legal rules. They must put efforts to transpire the wisdom of laws in generally and Islamic law in particular to the masses. The academic writings of legal academicians are a source of knowledge for legal practitioners while pleading the cases in the courts of law and for jurists also while adjudicating the litigation between the litigants.

The primary and foremost objective of Legal education is to educate the students for law practice in a particular jurisdiction. Law degree is pre-requisite for practicing law in the courts (Cheng Han, n.d). Legal practitioners (Bar) are entrusted with the responsibility to plead the cases in the courts of law. Therefore, learning of both Common legal tradition and Islamic legal tradition is necessary for lawyers so that they may lead the bench to a right direction while sorting out the answer of a question of law. For instance, section 28 of Limitation Act, 1908 was challenged in Federal Shariat Court in 1989 (PLD 1989 Federal Shariat Court 89, Maqbool Ahmad Qureshi Vs. The Government of Pakistan). Section 28 of Limitation Act, 1908 provides the legal rule about adverse passion which means the recognition of ownership by a person who possess the 
immoveable property for 20 years without interruption in case of private property and for 60 years without interruption in case of public property. In this case, the learned council of petitioner relied upon various references from Islamic law like reference was made from Al-Mabsūt by AlSarakhsī, Vol. 2, p. 48, 49 and 67. Similarly, reference was made from Bidāyat-al-Mujtahid by Ibn Rushd, Vol. 2, p. 244-245 and so on. It is evident from this example that legal practitioner needs the understanding of content knowledge of fiqh manuals to give evidences in support of his viewpoint.

Judiciary is an institution which is empowered to adjudicate upon the litigation by employing the skills of interpretation of the statutory provisions (Sial, 2009). Judges, while performing their duties, find difficulty whenever there is a question in a case before them relevant to the application of Islamic law. They seek the help of 'Ulamā' or Muslim jurists. Therefore, they appoint Muslim jurists as amicus curie or juris consult. This is the only way out for them to have answers of questions put to them relevant to the Shari 'ah viewpoint. It can be witnessed in a number of landmark cases. For the sake of example, one case is mentioned here. In a case of Maqbool Ahmad Qureshi vs. The Government of Pakistan, Hafiz Salahuddin Yousaf and Maulana Riaz Al-Hasan Noori were appointed as a Juris-consult.

\section{Conclusion and Recommendations}

This article intends to provide an overview of the current state of learning of Islamic law in contemporary universities. This article concludes that learning and teaching of Islamic law becomes relevant not only in Muslim states but also in Non-Muslim states in world today. Furthermore, it concludes that institutions where Islamic legal education is imparted along with the education in statutory law produce outstanding lawyers, academicians and jurists. Isolation of Sharī'ah from state law does not provide the solution of the issues. Rather, Shari 'ah is required to be integrated within the state law so that there might be a stage where a single legal system exists in Pakistan instead of having a mixed legal system or pluralistic legal system. To achieve this objective FSL of IIUI is striving hard and producing scholars as judges, lawyers and teachers who are well acquainted with the knowledge of Shari' 'ah (Islamic law) and statutory law (State law) also.

\section{References}

Aḥmad, Z. A. R. (2001). Tafsīr Ibn Rajab Al-Ḥanbalī. Saudi Arabia: Dōr-'Așmah.

Anderson, J. N. D. (Spring, 1980). "The Significance of Islamic Law in the World Today". The American Journal of Comparative Law. 9(2): 187-198. Retrieved from http://www.jstore.org/stable/837190. Accessed on $24^{\text {th }}$ February, 2019.

Cheng Han, T. Legal Education in ASEAN. Retrieved from https://www.researchgate.net/publication/238449058_Legal_Education_in_Asia.

Accessed on $1^{\text {st }}$ July, 2021.

David, R. and Brierley, J. E. C. (1978). $2^{\text {nd }}$ Edition. Major Legal Systems in the World Today: An Introduction to the Comparative Study of Law. U.S.A: Free Press Glencoe.

Hassan, H. H. (2010). An Introduction to the Study of Islamic Law. $10^{\text {th }}$ Edition. Islamabad: Shariah Academy International Islamic University Islamabad.

https://guides.law.sc.edu/c.php?g=315476\&p=2108388. Accessed on 8th March, 2019. https://ilsp.law.harvard.edu/who-we-are/. Accessed on 5th March, 2019.

https://www.harvard.edu/about-harvard/harvard-glance. Accessed on 5th March, 2019. https://www.iiu.edu.pk/?page_id=6881. Accessed on 10th March, 2019.

Jamali, A. Z. (Dec, 2015). Improving the Quality of Legal Education. Law and Justice Commission of Pakistan. Retrieved from http://ljcp.gov.pk/nljcp/assets/dist/Publication/32f71-legaleducation.pdf. Accessed on $4^{\text {th }}$ March, 2019.

Kayode, B. K. and Hashim, C. N. Quality Assurance in Contemporary Islamic Universities: 
Issues and Challenges. IIUM Journal of Educational Studies. 2(2): 40-58. Retrieved from http://www.researchagte.net/publication/306909564. Accessed on $2^{\text {nd }}$ March, 2019.

Khan, Z. A. (n.d). "Islam: A Deen not mere Religion", retrieved from http://www.qurtuba.edu.pk/thedialogue/The\%20Dialogue/4_1/05_zamir.pdf, accessed on 6th March, 2019.

Layish, A. (2014). Islamic Law in the Modern World: Nationalization, Islamization, Reinstatement. Islamic Law and Society. 21(1): 276-307. Retrieved from https://www.jstor.org/stable/i40131393. Accessed on $3^{\text {rd }}$ May, 2019.

Leghaei, S. M. (n.d). "Islam the first and last Religion", Retrieved from https://www.alislam.org/articles/islam-first-and-last-religion-shaykh-mansour-leghaei, accessed on 5th March, 2019.

Masud, M. K. (2005). "Teaching of Islamic Law and Shari'ah: A Critical Evaluation of the Present and Prospects for the Future". Islamic Studies. 44(2): 165-189, retrieved from http://www.jstore.org/stable/20838960, accessed on 24th February, 2019.

Minattur, J. (July-September, 1979). Major Legal Systems in the World Today. Journal of the Indian Law Institute. 21(3): 419-426. Retrieved from http://www.jstore.org/stable/43950645. Accessed on $6^{\text {th }}$ March, 2019.

Nyazee, I. A. (2016). Legal System of Pakistan. 1st edition. Islamabad: Federal Law House.

Nyazee, I. A. (2012). Outlines of Islamic Jurisprudence. Islamabad: federal Law House.

PLD 1989 Federal Shariat Court 89, Maqbool Ahmad Qureshi Vs. The Government of Pakistan.

Quran: Sūrah Al-Mā'ida: 3

Sial, A. Q. (2009). Designing Legal Education to Support Social Evolution in Pakistan. South Asian Studies. 24(2): 283-295. Retrieved from http://pu.edu.pk/images/journal/csas/PDF/8-A.Q.\%20Sial.pdf. Accessed on $4^{\text {th }}$ March, 2019. 